\title{
The Image Dispositif
}

\section{FRANCO BERARDI (BIFO)}

Imagination is a magic act. It's a spell which can make the things appear, so that you can hold them.

$$
\text { Jean-Paul Sartre, L'imaginaire }
$$

What is interesting is not the image as a representation of reality, but its dynamic power, its ability to stir up and build projections, interactions and narrative frames structuring reality. What is interesting in the image is its ability to select among infinite possible perceptual experiences, so that imagination becomes imagin/action.

Let's think of the image as a narrative dispositif (a disposing or structuring device); as a stratum of consciousness able to modify the projection of the body in space, in turn metamorphosing the meaning we attribute to our experience. Edmund Husserl says that 'consciousness is consciousness "of" something'. It means that consciousness is intentionality, a projection of a space, a temporal continuity where movement is made possible. Movement in time. Time in consciousness. Consciousness 'of' something. 
Representation 'presents again' the thing to consciousness, as if things already exist. In contrast, l'image mouvement that Deleuze is talking about provokes effects in consciousness, and predisposes consciousness to produce effects in the world. What we are interested in is the dynamic effect of the image, the action that image is producing on the body, on the world where the bodies meet and desire, and modify each other.

The technomedia mutation is inducing disturbances in the relationship between bodies, because it is producing disturbances in the elaboration of images, and pathologies in the intimate processing of the world and in relational projection. The main political task of our time, in the age of video-electronic media, is the creation of video-poetic strategies-in short, the creation of narrative frames for action, mythopoiesis, dispositifs for constructing new realities.

\section{-THE ELECTRO-CRUCIFIXION}

On 30 April 2004 when I saw in the newspapers the picture of the Iraqi detainee with a black hood and under threat of electrocution, I suddenly thought: 'Bush has lost his war'. Certainly since that moment, global perception of the war has changed, and something very deep cracked in the Western mind. The narrative broke free from the grip of the American military media system. Over the following month it became crystal clear that the process of global political and cultural transformation pivots on the production and transmission of images: the infosphere is producing narratives which move the consciousness of billions, affect the economy, investment and demand, as well as politics and electoral shifts, the explosions of violence and the formation of alliances.

The concept of public opinion seems inadequate to explain what is happening. It is not exactly opinion which matters (that is, doxa, critical discrimination between rational enunciations, consent and dissent and logical motivation). Instead I prefer to speak of imagination. Imagination is the dynamic space where the countless images that reach the collective consciousness are disposed in narrative formations. It is through the stratification of images on the changing surface of collective memory that dispositifs are built which can project reality; here psychic dispositifs model the attention to events, filtering the input of news, shaping emotional reactions, and finally influencing people's choice.

- THE MEDIASCAPE AND THE CRISIS OF ADVERTISING 
In the second half of the twentieth century, advertising became the general process for the production of the imagination, and it has sustained, motivated and directed most media production. TV has been a tool of advertising, financing the bulk of its huge production costs. The function of advertising is to expand and make fluid the consumption of commodities. In order to do so, it has built a global narrative centered on consumerism and security. The American middle class, according to Oliver Zunz, has been shaped by the diffusion of a narrative frame that is saying more or less: 'your life is trapped in the cage of endless work, but capitalism guarantees that in the leisure time you can buy gadgets and enjoy a relatively safe life'. ${ }^{1}$ This narrative frame has fallen apart in the new millennium. After the crisis of the new economy-which destroyed the illusion of a mass capitalism destined to boom endlessly- the 9/11 shock arrived.

TV has always shown catastrophes and violence. But in TV's narrative frame, violence is a spectacle which takes place afar, something that does not touch you personally. Sitting in your armchair, you enjoy the show. TV horror once provoked a reassuring effect. 'What happens on TV does not happen to me', the global middle class once thought. Suddenly this all changed on $9 / 11$. On that day the screen did something unpredictable, shocking the global psyche in an irremediable way. The screen showed what might be called 'fiction squared'. First, you see a tower which is smoking, because of an event we neither knew the cause of nor understood. Second, a scant twenty minutes later, just the time needed for TV stations across the globe to tune in, a revelation: an aeroplane is entering the second tower, destroying it. In that moment the fifty-year-old TV ontology was shattered. Was what we saw fiction or real information? In the following few minutes, everyone murmured or shouted that question. When we did understand that it was not fiction but information in the traditional sense, we knew the advertising loop had ended. The pact between message and receiver was broken.

Since then the mediascape initiated its divorce from advertising to enter a new marriage with terror. The narrative frame is no longer reassuring, each day promising a new dose of horror. Of course TV showed horror before 9/11, but it was spectacular, distant horror, with no effect for those in the armchair. Now the spectator has become a part of the show.

-THE ASYMMETRIC PSYCHOSPHERE 
May 2004. We can now understand something more about the war of images in the global infosphere. What happens in the infosphere is not determinable in linear terms, because it involves the psychosphere. The cognitive effect of a message depends neither solely on its explicit content nor on its redundancy. It also depends on factors that are difficult to determine in a conscious manner. There is always aleatory and aberrant decodification in the relationship between the mediascape and its social effects.

War is now a problem of influencing and controlling the global mind, with this control becoming increasingly aleatory and unpredictable. War not only shakes ground but also provokes heartquakes and conflicts in zones of social cognition, which exceed conscious ones. The Western nervous system is under a permanent stress whose effects cannot be predicted because they increasingly involve the collective unconsciousness. The good American boys and girls who have been sent to fight a war in the name of Good are going crazy. Their actions reveal an abyss of psychic misery. The Western mind mirrors itself in this abyss, and is on the verge of collapse.

The relationships inside the mediascape (the colonisation of mental time by the infoglow emanating from big corporations) influences the infosphere. However, the infosphere acts asymmetrically and thus unpredictably on the social mind (behaviour, the choices of people) via the psychosphere, the filter between the infosphere and the human mind. And the psychosphere is unstable: it is fragmenting and recombining the flow of images coming from the infosphere in a way which can be neither programmed nor predicted.

\section{—BLACK HOODS IN THE CITY}

In the piazzas of Bologna a group of activist have organised a performance: some blackhooded youth were singing a children's song mixed with the distressed American national anthem famously played by Jimi Hendrix. This kind of performance has been spontaneously repeated in many places across the world, in London, New York and Rome. What is its meaning? This action has been performed in order to draw out the horror, to put it on display for the urban citizenry of the West. You can take for granted that the black hood will be part of the mise en scène of anti-war demonstrations. What are the effects we want to provoke in the collective unconscious? What kind of effects will be provoked by the campaign of culpability initiated with the publication of the pictures from Abu Ghraib?

-THE IMAGE DISPOSITIF 
We must learn to target the effect of any action on the social imagination. We must be aware of the fact that images are today the basic political dispositif. By the word dispositif I refer to a semiotic engine able to act as the paradigm of a series of events, behaviours, narrations and projections modelling social reality. What effect may be produced by the black hood? I have not an unambiguous answer, but I know that a possible effect of the culpability campaign of the West could be a cynical assumption of racism. 'You accusing us of being racists? Well, we'll don the white hoods and start hunting, burning, hanging and killing Blacks and Muslims'. Remember the Ku Klux Klan emerged in 1862 as an effect of the culpability ascribed to the Southern life and ideology. And the KKK spirit is far from being extinguished in American culture.

The culpability and insularity of the American people could produce very dangerous effects. Only in November will we know if democratic fairness will prevail over the cynical and murderous compensation of self-hatred. The mise en scène of the black hoods is somehow related to Antonin Artaud's idea of theatre of cruelty: the ritualisation of violence can help to overcome the horror and need for revenge. But the path of therapy is not at all linear, and can give way to perverted outcomes. We must develop a scientific consciousness of the process of psychosocial consciousness, in order to improve our media action. We must think of the image as an interpretative and narrative dispositif.

September 2004

Translated by Marc Cote.

Franco Berardi (Bifo) is a philosopher and political activist. Co-founder of Rekombinant $<$ www.rekomdinant.org $>$, a web environment of informal communication, and media and political activism, he is also the author of numerous books. His most recent work, Il sapiente, il guerriero, il mercante, is currently being translated into English.

\footnotetext{
-NOTES

1 Olivier Zunz, Why the American Century?, University of Chicago Press, Chicago, 1998, p. 327.
} 